\title{
Leptin Stimulated C-Reactive Protein Production by Human Coronary Artery Endothelial Cells
}

\author{
Salvatore De Rosa Plinio Cirillo Mario Pacileo Vito Di Palma Antonella Paglia \\ Massimo Chiariello \\ Division of Cardiology, University of Naples Federico II, Naples, Italy
}

Key Words

Leptin $\cdot$ C-reactive protein $\cdot$ Statins

\begin{abstract}
Background: Obesity and cardiovascular disease are closely related. Leptin, an adipocyte-produced hormone, is associated with increased cardiovascular risk. Increased plasma levels of leptin are measurable in the plasma of obese individuals. However, the possible links between obesity and cardiovascular disease are not completely understood. C-reactive protein (CRP) is a predictor of future cardiovascular events and plays a role in atherothrombotic disease. Thus, we evaluated whether leptin might play a role in cardiovascular disease, investigating its effects on CRP production by human coronary artery endothelial cells in culture. Methods and Results: Leptin induced CRP mRNA transcription as demonstrated by semiquantitative and real-time polymerase chain reaction as well as the release of CRP in the culture medium in a concentration-dependent fashion. Leptin-induced production of CRP was mediated through the RhoA activation of protein kinase $C \beta$ since both protein kinase $C$ and $R$ hoA pathway inhibitors prevented these leptin effects. Lovastatin, a hydroxymethylglutaryl coenzyme A reductase inhibitor, by modulating the RhoA activation, significantly reduced leptin-induced CRP production. Conclusions: This study describes the close relationship between
\end{abstract}

leptin and CRP, providing support to the view that this adipokine, besides being involved in the pathophysiology of obesity, might play a relevant role as an active partaker in obesity, inflammation and atherothrombosis.

Copyright $\odot 2009$ S. Karger AG, Basel

\section{Introduction}

Emerging evidence has transformed the current point of view about adipose tissue, indicating that adipocytes should no longer be considered only for their role in fat storage, as they are being recognized as secretory cells. In fact, they are able to produce and secrete a large variety of active substances with proatherogenic effects on vascular cells, known as adipokines, which include leptin, adiponectin and resistin [1]. Several epidemiological studies have demonstrated that human obesity, a disease in which adipose tissue is largely represented, is associated with an increased incidence of cardiovascular events $[2,3]$. However, the possible pathophysiological mechanisms existing between these 2 clinical entities have not yet been completely investigated.

In this context, it is of particular interest that obese individuals frequently have elevated plasma levels of leptin [4]. Thus, it has been recently proposed that this adipokine, involved in the regulation of energy metabo- 
lism [5], might be a marker of increased cardiovascular risk, since several actions exerted by leptin on the cardiovascular system suggest involvement of this adipokine in the development of cardiovascular disease $[1,6-8]$.

Several experimental reports have indicated the close relationship between leptin, platelets and arterial thrombosis $[6,7]$. Thus, these experimental data support the hypothesis that leptin might be involved in the pathophysiology of acute coronary syndromes. Indeed, several clinical studies have underlined that increased plasma levels of leptin are associated with an increased risk of developing myocardial infarction [9] and stroke [10]. Again, increased serum leptin concentrations have been measured in patients with ST-elevated myocardial infarction [11]. In addition, a large prospective study on leptin and cardiovascular risk performed on the West of Scotland Coronary Prevention Study (WOSCOPS) population confirmed that leptin is an independent predictor of coronary events [12]. More recently, this adipokine has been indicated as a powerful prognostic marker of future cardiovascular events, in patients with angiographically documented coronary atherosclerosis [13].

C-reactive protein (CRP) has been demonstrated to be an important predictor of future cardiovascular events both in patients with documented cardiovascular disease and in an apparently healthy population [14-16]. Starting from these clinical observations, a growing body of experimental evidence has demonstrated that this acutephase protein plays an active role in the pathophysiology of atherothrombotic disease [17-19]. CRP, like other acute-phase proteins, is usually synthesized by the liver following stimulation by cytokines, such as IL-1, IL- 6 and tumor necrosis factor [20]. Indeed, some recent reports have evidenced that this protein can be produced by other cell types, including smooth muscle cells [21] and adipocytes [22]. Furthermore, increased levels of CRP have been found in atherosclerotic arteries [23], as well as in saphenous venous bypass grafts [24]. Interestingly, elevated plasma levels of CRP have been observed in obese adults [25].

The aim of the present study was to investigate whether leptin, besides having effects on the regulation of the energy metabolism, might play an active role in the pathophysiology of coronary atherothrombotic disease. In particular, we have postulated that leptin, by stimulating the production of CRP in human coronary endothelial cells, may lead to atherosclerotic and thrombotic coronary complications. Finally, we have investigated some of the molecular mechanisms potentially involved in the modulation of this phenomenon.

\section{Methods}

Human coronary artery endothelial cells (HCAECs; Cambrex Bio Science, Walkersville, Md., USA) were grown in EGM-2 medium with endothelial cell growth supplement and $10 \%$ fetal serum. Cells were used at passages 2-5. To investigate the effects of leptin on CRP production, cells were cultivated in 6-well culture plates, while for the other set of experiments, cells were grown in 100 -mm cell plates.

Given the concern about the potential contamination with endotoxin, leptin (Sigma Chemical Co., St. Louis, Mo., USA) used in all studies described was analyzed with an endotoxin level $<0.125 \mathrm{EU} / \mathrm{ml}(<12.5 \mathrm{pg} / \mathrm{ml})$ by Limulus assay (BioWhittaker, Walkersville, Md., USA). All the media and water were tested as well, and the endotoxin level was found to be $<0.125 \mathrm{EU} / \mathrm{ml}$.

Effects of Leptin on CRP $m$ RNA Levels

HCAECs were grown in $100-\mathrm{mm}$ cell plates and, at confluence, cell density was about $2 \times 10^{6}$ cells per plate. Then, HCAECs were incubated for $48 \mathrm{~h}$ with leptin ( 5 and $10 \mathrm{ng} / \mathrm{ml}$ ). This range included the mean leptin concentration observed in plasma of patients with coronary disease $[10,11]$. CRP mRNA levels were measured by semiquantitative polymerase chain reaction (PCR) and by real-time quantitative reverse transcription (RT)-PCR. Total RNA was extracted by Trizol reagent at baseline and after $48 \mathrm{~h}$ of leptin stimulation. cDNA was obtained by RT-PCR using $2 \mu \mathrm{g}$ of total RNA and esanucleotide random primers; specific CRP cDNA was obtained using specific primers: $5^{\prime}$-TCGTATGCCACCAAGAGACAAGACA-3' and 5'-ACACTTCGCCTTGCACTTCATACT-3' (GenBank accession No. M11725), corresponding to a 400-bp fragment length of CRP. Each cycle consisted of a denaturation step at $96^{\circ} \mathrm{C}$ for $1 \mathrm{~min}$, an annealing step at $62^{\circ} \mathrm{C}$ for $1.5 \mathrm{~min}$ and an elongation step at $72^{\circ} \mathrm{C}$ for $4 \mathrm{~min}$. RTPCR products were separated by electrophoresis on a $1 \%$ ethidium bromide-agarose gel and their intensities were quantified by a laser densitometry. Housekeeping GAPDH mRNA was simultaneously amplified as internal control. In positive control experiments, HCAECs were stimulated with lipopolysaccharide (LPS; $50 \mu \mathrm{g} / \mathrm{ml}$ ). Three different experiments were performed for each experimental condition.

Real-time RT analysis was performed as previously described [17]. HCAECs were incubated with increasing leptin concentrations as above. Total mRNA was extracted at baseline and $48 \mathrm{~h}$ after leptin stimulation. CRP mRNA levels were examined by real-time RT and PCR by LightCycler (Roche Diagnostics, Basel, Switzerland). Specific primers for real-time PCR were designed: 5'-GTGTTTCCCAAAGAGTCGGATACT-3' and 5'-CCACGGGTCGAGGACAGTT-3'. In positive control experiments, HCAECs were incubated with LPS $(50 \mu \mathrm{g} / \mathrm{ml})$.

Three different experiments were performed for each experimental condition.

\section{Effects of Leptin on CRP Production}

Cells were cultured in 6-well culture plates until about $90 \%$ confluence. The same cell density was used for each experimental condition, i.e. $1.5 \times 10^{5}$ cells per plate. Leptin $(5,10$ or $20 \mathrm{ng} / \mathrm{ml})$ or LPS $(50 \mu \mathrm{g} / \mathrm{ml})$ was then added to the medium (total medium volume per well was $1.5 \mathrm{ml}$ ). After stimulation, cells were incubated for $48 \mathrm{~h}$. At the end of the incubation period, the culture supernatants were collected and concentrated $\times 10$ using centrif- 
ugal filter units Amicon Ultra (Millipore, Billerica, Mass., USA). Then, CRP levels were measured using a commercial ELISA kit specific for human CRP (DSL Inc., Webster, Tex., USA) according to the manufacturer's directions. Briefly, standards, controls and samples were incubated for $30 \mathrm{~min}$ at room temperature in 96 well plates which were coated with anti-Ultra Sensitive CRP antibody. After incubation and washing, the wells were treated for 15 min at room temperature with another anti-US CRP detection antibody labeled with the enzyme horseradish peroxidase. After a second incubation and washing step, the wells were incubated for $10 \mathrm{~min}$ at room temperature with the substrate tetramethylbenzidine $(100 \mu \mathrm{l})$. Stop solution was then added and the degree of enzymatic turnover of the substrate was determined by dual wavelength absorbance measurement at $450 \mathrm{~nm}$. All the experiments were repeated 6 times. In an additional set of experiments, HCAECs were preincubated for $30 \mathrm{~min}$ with cycloheximide (10 $\mu \mathrm{g} / \mathrm{ml})$, an inhibitor of protein synthesis, before being stimulated with leptin $(10 \mathrm{ng} / \mathrm{ml})$ in order to evaluate whether leptin-induced CRP production was due to de novo synthesis. As it has been suggested that oxidative stress might be a fundamental principle of the mode of operation of leptin [24], in another set of experiments, CRP production was evaluated as above, but in cells preincubated for $30 \mathrm{~min}$ in the presence of the free radical scavenger superoxide dismutase (SOD, $500 \mathrm{U} / \mathrm{ml}$ ).

To investigate the molecular mechanisms involved in leptininduced CRP production, in additional experiments, $30 \mathrm{~min}$ before being stimulated with leptin $(10 \mathrm{ng} / \mathrm{ml})$, HCAECs were pretreated with pyrrolidine-dithiocarbamate ammonium (PDTC, $100 \mu \mathrm{M})$, an inhibitor of the transcription factor nuclear factor- $\kappa \mathrm{B}$

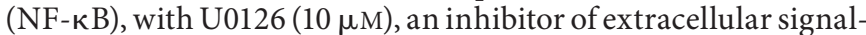
regulated kinases (ERKs), with Gö-6983 (200 nM), an inhibitor of protein kinase C (PKC), or with Y-27632 (1 $\mu \mathrm{M})$, an inhibitor of Rho kinase.

Finally, to evaluate whether statins might modulate the effects of leptin on CRP production, HCAECs were cultured in EGM-2 medium enriched with lovastatin $(5 \mu \mathrm{M})$. Then, cells were exposed to leptin $(10 \mathrm{ng} / \mathrm{ml})$ and processed as above to evaluate CRP production. In control experiments, cells were cultured in medium enriched with lovastatin as discussed above plus mevalonate $\left(10^{-4} \mathrm{~mol} / \mathrm{l}\right.$; Sigma Chemical Co.), before being stimulated with leptin $(10 \mathrm{ng} / \mathrm{ml})$.

Six different experiments were performed for each experimental condition.

Effects of Leptin on CRP Production: Molecular Mechanisms Rho Activity

The activation of RhoA was assessed by an enzyme-linked immunosorbent assay (ELISA)-based RhoA activity assay (G-LISA; Cytoskeleton, Denver, Colo., USA) according to the manufacturer's instructions. In brief, HCAECs were grown as above and incubated with leptin $(10 \mathrm{ng} / \mathrm{ml})$. In control experiments, HCAECs were cultivated in medium enriched with lovastatin $(5 \mu \mathrm{M})$ or with lovastatin plus mevalonate $\left(10^{-4} \mathrm{~mol} / \mathrm{l}\right)$, before being stimulated with leptin $(10 \mathrm{ng} / \mathrm{ml})$. Finally, in an additional set of experiments, cells were cultivated in medium enriched with Gö$6983(200 \mathrm{nM})$ or with SOD $(500 \mathrm{U} / \mathrm{ml})$ before stimulation with leptin as above. Then, cells were washed with ice-cold Tris-buffered saline and lysed as per the G-LISA protocol using lysis buffer provided in the kit. The lysates were incubated in microwells to which the rhotekin binding domain peptide was bound, and ac- tive RhoA was detected using indirect immunodetection followed by a colorimetric reaction measured by absorbance at $490 \mathrm{~nm}$. Six different experiments were performed for each experimental condition.

\section{PKC $\beta$ Activity}

HCAECs were cultured in 100-mm plates and, at about $90 \%$ confluence, were incubated with leptin $(10 \mathrm{ng} / \mathrm{ml})$ or with LPS (50 $\mu \mathrm{g} / \mathrm{ml}$ ) as positive control. In additional experiments, PKC activity was measured in cells pretreated with lovastatin $(5 \mu \mathrm{M})$, lovastatin plus mevalonate ( $\left.10^{-4} \mathrm{~mol} / \mathrm{l}\right), \mathrm{Gö}-6983$ (200 nM) and with the Rho pathway inhibitor Y-27632 (1 $\mu \mathrm{M})$, before being stimulated with leptin $(10 \mathrm{ng} / \mathrm{ml})$

Cells were harvested with lysis buffer (Tris-HCL $50 \mathrm{mM}, \mathrm{NaCl}$ $100 \mathrm{~mm}, \mathrm{MgCl}_{2} 10 \mathrm{~mm}$, EDTA $2 \mathrm{~mm}$, NP-40 1\%, Triton X-100 $0.1 \%$, phosphatase inhibitor cocktail, DTT, $\mathrm{pH} 7.5$ ).

\section{Western Blotting}

Equal amounts (approximately $50 \mu \mathrm{g} / \mathrm{sample}$ ) of protein were combined with Laemmli's Sample Buffer containing 5\% (vol/vol) $\beta$-mercaptoethanol and boiled for $5 \mathrm{~min}$. Proteins were separated by electrophoresis on 7.5\% SDS-PAGE gels and blotted to nitrocellulose membranes. The protein-bound nitrocellulose sheets were incubated overnight at $4^{\circ} \mathrm{C}$ in a blocking buffer $(20 \mathrm{~mm}$ Tris, $\mathrm{pH}$ $7.5,500 \mathrm{~mm} \mathrm{NaCl}, 5 \%$ nonfat dry milk). Nitrocellulose sheets were then incubated with the isozyme-specific monoclonal antibody anti-PKC $\beta$ (Transduction Laboratories, Lexington, Ky., USA) diluted in the blocking buffer (PKC $1: 5,000)$ for $1 \mathrm{~h}$ at room temperature and rinsed for $30 \mathrm{~min}$ with a wash buffer $(20 \mathrm{mM}$ Tris, pH 7.5, $500 \mathrm{~mm} \mathrm{NaCl}, 0.2 \%$ Tween-20). Finally, membranes were incubated with peroxidase-conjugated sheep anti-mouse IgG antibody (1:3,000; Amersham Corp, Louisville, Colo., USA) for $1 \mathrm{~h}$ at room temperature and washed for $30 \mathrm{~min}$. PKC $\beta$ bands were visualized with enhanced chemiluminescence detection reagents.

PKC $\beta$ Activity Assay

HCAECs incubated as above were processed with the TruLight PKC $\beta I /$ II Kinase Assay Kit (Calbiochem, Darmstadt, Germany) according to the manufacturer's instructions. PKC $\beta$ activity was expressed as fluorescence signal due to serine phosphorylation of the following substrate peptide: RFARKGSLRQKNV.

\section{Statistical Analysis}

Data are presented as the mean \pm SD. Differences between groups were determined by a one-way ANOVA followed by a Student's $t$ test with Bonferroni's correction. A p value $<0.05$ was considered statistically significant.

\section{Results}

\section{Effects of Leptin on CRP mRNA Levels}

Semiquantitative RT-PCR showed that CRP mRNA levels were almost undetectable in unstimulated cells. Similarly, low CRP mRNA levels were observed in cells stimulated with leptin at a low concentration $(5 \mathrm{ng} / \mathrm{ml})$. Vice versa, in cells stimulated with leptin at a concentra- 


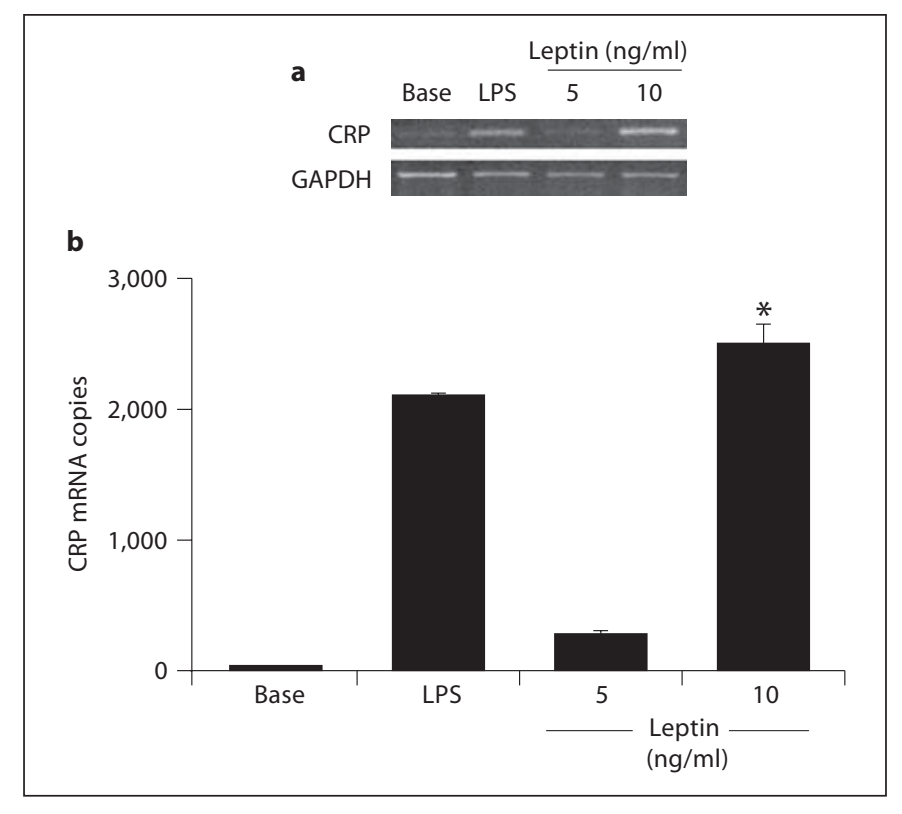

Fig. 1. Effects of leptin on CRP mRNA. a Result of a typical semiquantitative RT-PCR. A slight increase in CRP mRNA levels is already evident at a low leptin concentration $(5 \mathrm{ng} / \mathrm{ml})$, with more evident increase at a higher leptin concentration $(10 \mathrm{ng} / \mathrm{ml})$. LPS served as positive control. b Results of quantitative real-time PCR experiments are shown in the bar graph. While a slight increase in CRP mRNA levels is observed after stimulation with leptin at $5 \mathrm{ng} / \mathrm{ml}$, a significant increase is evident at higher concentrations $(10 \mathrm{ng} / \mathrm{ml})$. In the bar graph, results are reported as the mean \pm SD from 3 separate real-time RT-PCR experiments. ${ }^{*} \mathrm{p}<0.005$ vs. Base.

tion usually measured in the plasma of patients with coronary artery disease [11], or with an increased risk of developing a future acute cardiac event $(10 \mathrm{ng} / \mathrm{ml})$ [12], a significant increase in CRP mRNA levels was observed. (fig. 1a). Quantitative real-time PCR experiments showed undetectable levels of CRP mRNA at baseline. A slight increase in CRP mRNA copies was observed after stimulation with leptin at low concentrations ( $5 \mathrm{ng} / \mathrm{ml})$, while a significant increase in CRP mRNA copies was measurable with higher leptin concentrations (fig. 1b).

\section{Effects of Leptin on CRP Secretion}

CRP levels were almost undetectable in the culture medium of unstimulated cells. In a preliminary set of experiments, we have investigated the time course of CRP secretion in culture medium after leptin stimulation, observing that CRP levels peaked at $48 \mathrm{~h}$ (data not shown). Thus, we have investigated the effects of increasing leptin concentrations on CRP production at this time point by high-sensitivity ELISA.
Leptin induced the increase in CRP levels in cell culture medium in a dose-dependent fashion (fig. 2a). Interestingly, a significant increase in CRP levels was observed when cells were stimulated with leptin concentrations similar to those detected in the plasma of patients with coronary artery disease $[10,11]$.

These effects of leptin on CRP production were significantly prevented by preincubation with cycloheximide $(10 \mu \mathrm{g} / \mathrm{ml})$, an inhibitor of protein synthesis, before stimulation with leptin $(10 \mathrm{ng} / \mathrm{ml})$, suggesting de novo synthesis of CRP (fig. 2b). Similarly, in cells preincubated with the free radical scavenger SOD, leptin failed to induce CRP production, suggesting that these highly reactive oxygen-derived molecules play an important role in mediating leptin effects (fig. 2b).

To investigate the molecular mechanisms involved in the modulation of leptin-induced CRP production, endothelial cells were pretreated with PDTC $(100 \mu \mathrm{M})$, an inhibitor of the transcription factor NF- $\kappa \mathrm{B}, \mathrm{U} 0126(10 \mu \mathrm{M})$, an inhibitor of ERKs, and Gö-6983 (200 nM), an inhibitor of PKC, before stimulation with leptin $(10 \mathrm{ng} / \mathrm{ml})$. Interestingly, Gö-6983 significantly prevented leptin-induced CRP production, whereas neither PDTC nor U0126 had an effect on this phenomenon, suggesting that leptin promotes CRP production through the PKC pathway (fig. 2c). Moreover, preincubation with the hydroxymethylglutaryl coenzyme A (HMG-CoA) reductase inhibitor, lovastatin, significantly prevented leptin effects on CRP. A similar effect was observed in cells preincubated with the Rho kinase inhibitor Y-27639 $(1 \mu \mathrm{M})$. The inhibitory effect of lovastatin was reversed by mevalonate (fig. 3). Mevalonate by itself did not affect leptin-induced CRP production (data not shown).

\section{Effects of Leptin on CRP Production: Molecular \\ Mechanisms \\ Rho Activity}

The activation of RhoA was assessed by an ELISAbased RhoA activity assay. As shown in figure 4, leptin caused activation of RhoA. Pretreatment with lovastatin prevented these leptin effects. Lovastatin effects were reversed by mevalonate. In cells incubated with SOD, leptin did not induce RhoA activation. Finally, in cells incubated with Gö-6983, leptin induced activation of RhoA, suggesting that the PKC pathway does not affect leptin-induced RhoA activity.

\section{PKC $\beta$ Activity}

Having observed that Gö-6983 significantly reduced leptin effects on CRP production, in additional experi- 


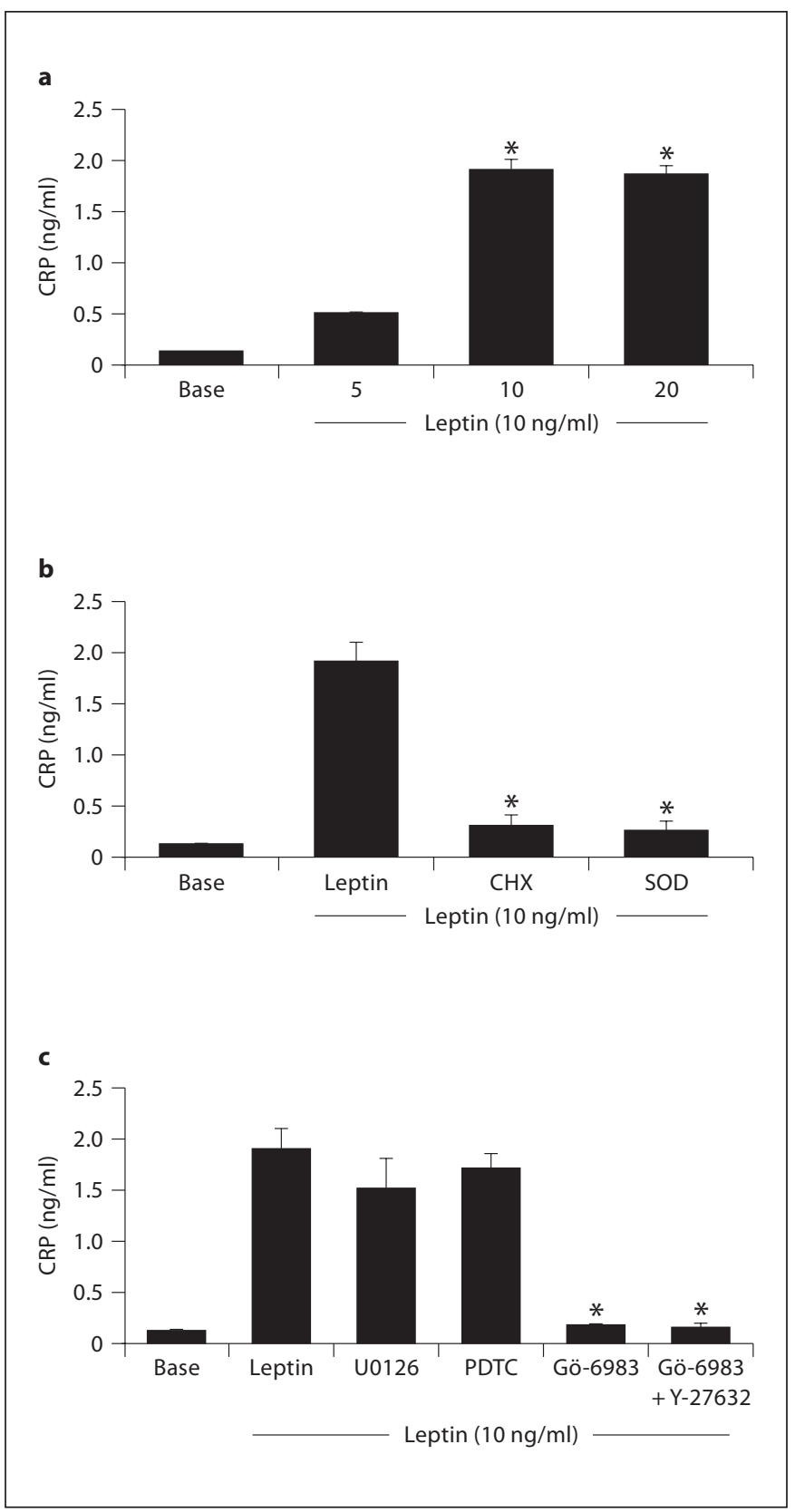

Fig. 2. Effects of leptin on CRP production. a Leptin-induced CRP production in a dose-dependent fashion. b Preincubation with cycloheximide (CHX, $10 \mu \mathrm{g} / \mathrm{ml})$, an inhibitor of protein synthesis, or with SOD $(500 \mathrm{U} / \mathrm{ml})$, an oxygen-free radical scavenger, before stimulation with leptin $(10 \mu \mathrm{g} / \mathrm{ml})$, significantly reduced CRP production. c Gö-6983 significantly prevented leptin-induced CRP production, whereas PDTC and U0126 had no effect on this phenomenon. Simultaneous inhibition with Gö-6983 and Y-27632 had a similar effect to Gö-6983 alone. Each bar represents the mean \pm SD of 6 experiments. ${ }^{*} p<0.005$ versus leptin. Leptin concentration was measured on cell supernatants obtained after $48 \mathrm{~h}$ stimulation in 6-well plates in a total medium volume of 1.5 $\mathrm{ml} /$ well after $\times 10$ concentration. The same cell density was used for each experimental condition, being $1.5 \times 10^{5}$ cells per plate.

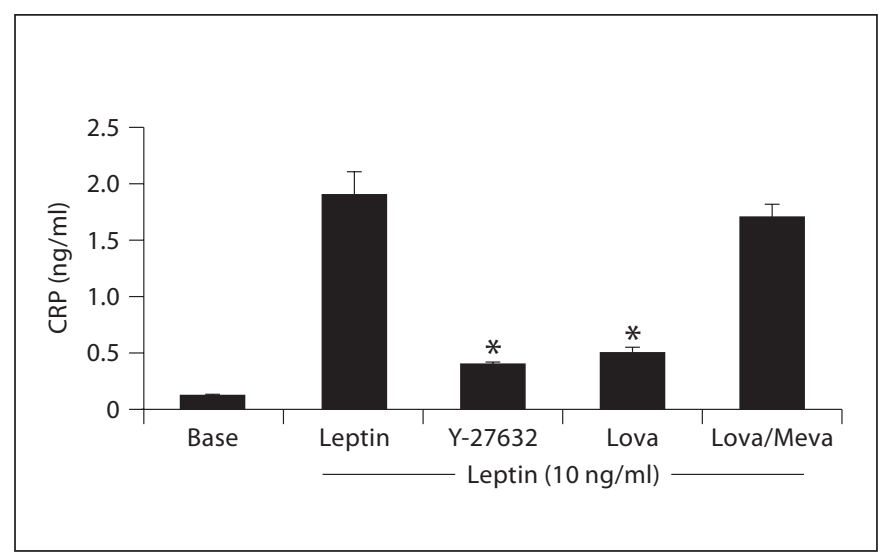

Fig. 3. Effects of statins on leptin-induced CRP production. Lovastatin (Lova, $5 \mu \mathrm{M}$ ) significantly reduced leptin-induced CRP production. This effect was reverted by mevalonate (Meva, 100 $\mu \mathrm{M})$. Y-27632 significantly reduced leptin-induced CRP production, similarly to lovastatin. Each bar represents the mean \pm SD of 6 experiments. ${ }^{*} \mathrm{p}<0.005$ versus leptin.

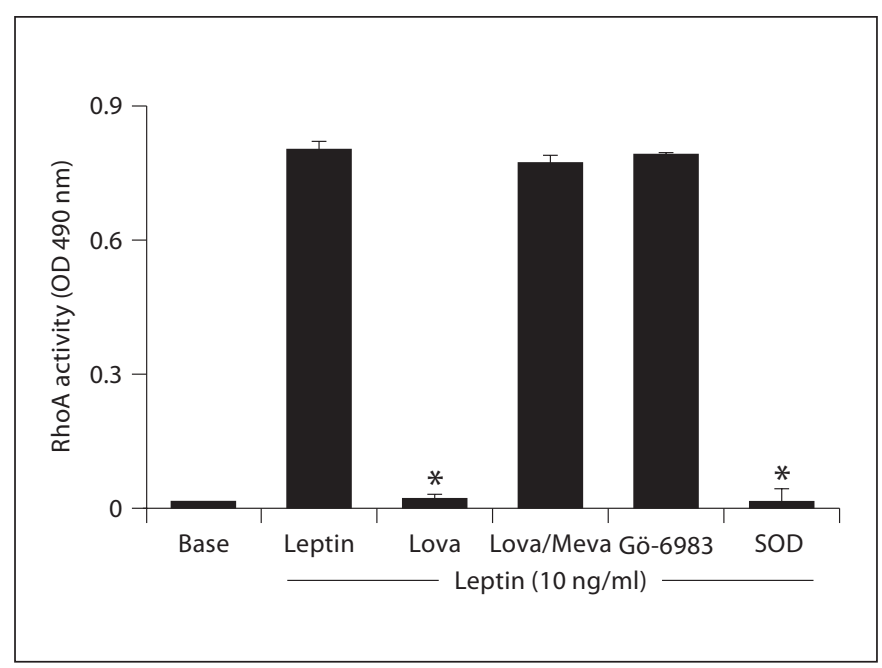

Fig. 4. Effects of leptin on RhoA activity. Leptin induced RhoA activation. Both treatment with lovastatin (Lova) and SOD prevented leptin-induced activation of RhoA, whereas mevalonate (Meva) addition nullified the lovastatin effect. PKC inhibition with Gö-6983 had no effect on RhoA activation. Each bar represents the mean $\pm \mathrm{SD}$ of 6 experiments. $\mathrm{OD}=$ Optical density. ${ }^{*} \mathrm{p}<0.005$ versus leptin. 


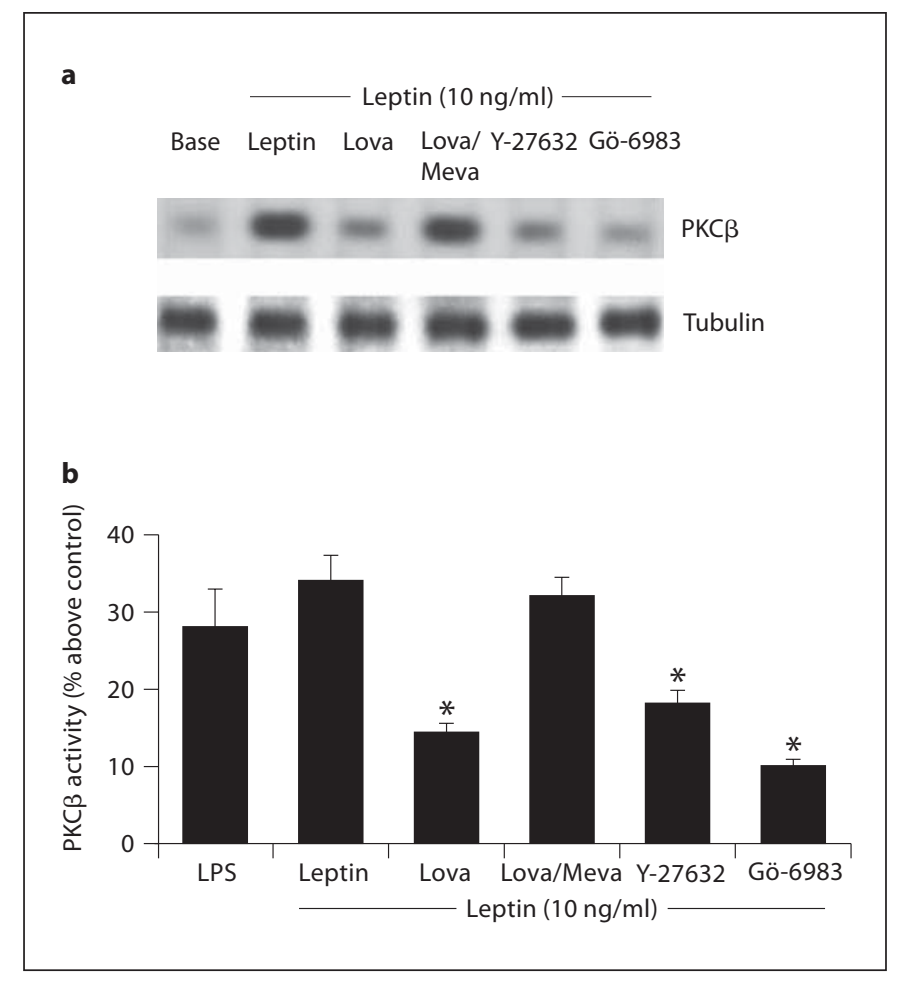

Fig. 5. Effects of leptin on PKC $\beta$ activity. a The insert reports the results of Western blot for PKC $\beta$. Increase levels of PKC $\beta$ are evident after stimulation with leptin. Treatment with lovastatin prevented leptin effects on PKC $\beta$, whereas mevalonate (Meva) nullified the lovastatin (Lova) effect. Both treatment with Y-27632 and Gö-6983 inhibited leptin effects on PKC $\beta$. b At the kinase activity assay, leptin $(10 \mathrm{ng} / \mathrm{ml})$ caused a significant increase in PKC $\beta$ activation. Pretreatment of cells with the PKC inhibitor Gö-6983 significantly reduced leptin-dependent PKC $\beta$ activation. Lovastatin as well as Y-27632 $(10 \mu \mathrm{M})$ exerted similar effects on PKC $\beta$ activity induced by leptin.

ments, we have directly evaluated the effects of leptin on phosphorylation of a specific substrate peptide by PKC $\beta$. Stimulation of cells with leptin $(10 \mathrm{ng} / \mathrm{ml})$ caused a significant increase in PKC $\beta$ activation, with $30.3 \%$ increase above control at high-sensitivity fluorescence-based assay. As expected, pretreatment of cells with the PKC inhibitor Gö-6983 (200 nM) significantly reduced leptindependent $\mathrm{PKC} \beta$ activation (8.9\% increase in phosphorylation of the substrate above control). Interestingly, lovastatin as well as Y-27632 $(1 \mu \mathrm{M})$ significantly reduced PKC $\beta$ activity induced by leptin (13.8 and $16.2 \%$ increase in the phosphorylation of substrate, respectively, above control; fig. 5b), but this effect was less pronounced than that observed with Gö-6983.

\section{Discussion}

The main findings of the present study are: (1) leptin induces CRP mRNA transcription and de novo synthesis of this inflammatory protein in HCAECs in culture; (2) this phenomenon seems to be mediated via oxygen-free radicals and through RhoA-dependent activation of PKC; (3) lovastatin, an HMG-CoA reductase inhibitor, prevents these leptin effects by modulating the RhoA activation.

Emerging evidence has transformed the current point of view about adipose tissue, indicating that adipocytes should no longer be considered only for their role in fat storage, as they are being recognized as secretory cells. In fact, they are able to produce and secrete a large variety of active substances with proatherogenic effects on vascular cells, known as adipokines, which include leptin, adiponectin and resistin [1]. Indeed, several epidemiological studies have clearly demonstrated that human obesity, a disease in which adipose tissue is largely represented, is causally related to cardiovascular disease [2,3]; however, the possible pathophysiological link existing between these 2 clinical entities has not yet been completely investigated.

Among the adipokines, leptin seems to exert several peripheral effects, independently of its role in the regulation of energy balance and body weight [5]. In fact, leptin receptors have been identified on several cell types [26]. Again, increased plasma leptin levels appear to be correlated with cardiovascular disease, and this effect is independent from body mass index and traditional risk factors $[4,9,10,13]$. Experimental studies have demonstrated that this adipokine is involved in the pathophysiology of arterial thrombosis mediated by platelet activation and that leptin-deficient and leptin receptor-deficient mice are protected from arterial thrombosis and vascular remodeling after arterial wall injury $[6,7]$.

In recent years, an impressive mass of data has assigned an important role to inflammation as a phenomenon linked to the clinical occurrence of acute coronary syndromes $[14,15]$. In this respect, several epidemiological studies have demonstrated that CRP, a marker of inflammation, is an important prognostic factor for the future occurrence of major cardiovascular events, both in patients with known cardiovascular disease and in apparently healthy subjects [14-16]. However, CRP is no longer to be considered as a simple marker of inflammation and future cardiovascular events; today, it is rather indicated as an active partaker involved in the pathophysiology of atherothrombosis [17-19]. 
Like other acute-phase proteins, CRP is usually synthesized by the liver following stimulation by cytokines, such as IL-1, IL-6 and tumor necrosis factor [20]. Recent reports have evidenced that this protein can be produced by other cell types as well, including smooth muscle cells [21] and adipocytes [22]. Importantly, local generation of CRP has been observed in atherosclerotic arteries and in saphenous venous bypass grafts [23,24]. This might have important pathophysiological implications, giving the relevant role played by CRP in the development of atherothrombotic disease.

In the present study, we show that leptin, at clinically relevant concentrations similar to those usually measured in plasma of patients with an increased risk of cardiac event [12], with acute myocardial infarction [11] or with documented coronary artery disease [13], also induces the production of CRP by HCAECs in culture. These results suggest a new possible link between increased plasma levels of leptin and vascular inflammation as a cause of increased cardiovascular risk as well as of acute cardiovascular events.

It has been recently demonstrated, in a similar experimental setup, that leptin is able to induce CRP production in endothelial cells [27]. In the latter study, the authors investigated the effects exerted by elevated leptin concentrations (usually measurable in plasma of obese individuals) in stimulating CRP production, as the lowest concentration tested was $50 \mathrm{ng} / \mathrm{ml}$, and concluded that their results were supportive of a proatherogenic effect of leptin at concentrations seen in obesity. In the present study, we have investigated the effects exerted by leptin concentrations in a range usually observed in plasma of patients with increased cardiovascular risk that is about $9 \mathrm{ng} / \mathrm{ml}$ [13]. Interestingly, it was recently shown that leptin at these concentrations $(0.5-10 \mathrm{ng} / \mathrm{ml})$ induces CRP expression in primary human hepatocytes in culture [28]. In addition, Singh et al. [27] did not measure CRP concentrations in cell supernatants, while in the present study, these concentrations were $2 \mathrm{ng} / \mathrm{ml}$. This is an important issue considering that this concentration is below the CRP range described as coronary risk factor, i.e. $1 \mu \mathrm{g} / \mathrm{ml}$ [16]. Taken together, these data permit to postulate that leptin at concentrations used in the present study and usually observed in plasma of patients with increased cardiovascular risk are able to continuously stimulate CRP production in the liver and, more importantly, in endothelial cells of coronary circulation, leading to a proinflammatory state. In turn, increased CRP concentrations at the coronary site might promote smooth muscle cell proliferation as well as tissue factor expression in endothelial cells [19]. Thus, leptin, at these concentrations, might finally lead to atherosclerotic and thrombotic coronary complications.

Oxidative stress seems to play a fundamental role in the mode of operation of leptin [29]. Indeed, in line with this observation, data of the present study support this hypothesis since SOD, a scavenger for oxygen-free radicals, by inhibiting oxygen-free radical-mediated activation of RhoA significantly reduced leptin effects on CRP production.

Interestingly, another important issue of the present study that was not investigated by Singh et al. [27] was that HMG-CoA reductase inhibition was able to prevent leptin effects on CRP production. In particular, we wanted to study whether a lipid-lowering agent, lovastatin, might exert protective effects on leptin-induced production of CRP in endothelial cells independently of its lipidlowering action. Thus, in the present study, we have demonstrated that lovastatin significantly reduced leptin-induced CRP production in coronary endothelial cells. The reduction in CRP production was reversed by mevalonate, suggesting that inhibition of the 'mevalonate pathway' mediates this phenomenon. This intracellular biosynthetic pathway generates geranylgeranyl pyrophosphate as an intermediate, which is known to be fundamental for Rho activation [30,31]. Indeed, statin mechanism of action foresees the inhibition of Rho isoprenylation and, in vascular cells, this seems to be the main mechanism to explain the antioxidant effects of statins. In particular, Laufs et al. [31] have demonstrated upregulation of endothelial nitric oxide synthase and increased nitric oxide production after statin treatment, an effect likely to produce overall antioxidant action. Indeed, in the present study, Y-27632, the Rho kinase inhibitor, significantly reduced leptin-induced production of CRP. Thus, it might be speculated that statins, by inhibiting Rho activation, exerted an antioxidant effect, finally leading to the inhibition of CRP production in leptinstimulated endothelial cells.

The molecular mechanisms responsible for leptin effects on vascular cells are not completely defined, since previous reports have demonstrated that both NF- $\kappa \mathrm{B}$ and ERK pathways are involved in leptin mechanism of action [32]; at the same time, other studies have demonstrated that leptin effects could be mediated by PKC activation, independently of other cellular pathways [33].

In this context, another interesting finding of the present study is that leptin-induced CRP production in a cell population never studied before, such as the coronary endothelial cells, was mediated by the activation of PKC, 
while NF- $\kappa \mathrm{B}$ and ERK do not seem to be involved in this phenomenon. Indeed, Gö-6983, a PKC inhibitor, significantly reduced leptin effects, whereas PDTC, a selective NF- $\kappa \mathrm{B}$ inhibitor, and U0126, a selective ERK inhibitor, did not affect leptin-induced CRP production. Results of the present study seem to be in contrast with those of Singh et al. [27]. Indeed, they have evaluated ERK activation in cells acutely stimulated with leptin for $30 \mathrm{~min}$ while we have evaluated leptin effects after $48 \mathrm{~h}$, when it is likely that ERK activation is no longer involved in the leptin mechanism of action. This hypothesis seems to be in line with a previous work by Blanquicett et al. [34] in which they demonstrated that acute leptin exposure (30$60 \mathrm{~min}$ ) of HCAECs increased eNOS phosphorylation and caused ERK activation. In contrast, prolonged leptin stimulation failed to alter eNOS expression, phosphorylation and ERK activation.

Interestingly, lovastatin inhibited leptin-induced PKC activation. This finding is in line with other reports de- scribing that statins may directly act on PKC $\beta$ [35]. In addition, previous reports have indicated that Rho might be involved in the activation of PKC [36] and that Rho/ Rho kinase and PKC pathways are functionally correlated [37]. Again, Hippenstiel et al. [38] have described that inhibition of Rho protein blocked PKC translocation and activation in endothelial cells. Thus, it might be speculated that leptin effects on CRP expression are mediated through activation of RhoA which, in turn, causes activation of PKC. Lovastatin significantly reduces leptin effects in coronary endothelial cells by inhibiting RhoA activation and, consequently, PKC.

In conclusion, data from the present study - although in vitro - represent the first evidence that leptin induces CRP production by human coronary endothelial cells, providing a local source of CRP that can play a direct role in promoting atherothrombosis in the coronary tree.

Further studies are warranted to clarify whether these mechanisms are also important in the clinical setting.

\section{References}

1 Berg AH, Scherer PE: Adipose tissue, inflammation, and cardiovascular disease. Circ Res 2005;96:939-949.

$\checkmark 2$ Sowers JR: Obesity as a cardiovascular risk factor. Am J Med 2003;115:37-41.

3 Hubert HB, Feinleib M, McNamara PM, Castelli WP: Obesity as an independent risk factor for cardiovascular disease: a 26-year follow-up of participants in the Framingham Heart Study. Circulation 1983;67:968-977.

4 Considine RV, Sinha MK, Heiman ML, Kriauciunas A, Stephens TW, Nyce MR, Ohannesian JP, Marco CC, McKee LJ, Bauer TL, Caro JF: Serum immunoreactive-leptin concentrations in normal-weight and obese humans. N Engl J Med 1996;334:292-295

$\checkmark 5$ Jequier E: Leptin signaling, adiposity, and energy balance. Ann NY Acad Sci 2002;967: 379-388.

-6 Bodary PF, Westrick RJ, Wickenheiser KJ, Shen Y, Eitzman DT: Effect of leptin on arterial thrombosis following vascular injury in mice. JAMA 2002;287:1706-1709.

7 Konstantinides S, Schäfer K, Koschnick S, Loskutoff DJ: Leptin-dependent platelet aggregation and arterial thrombosis suggests a mechanism for atherothrombotic disease in obesity. J Clin Invest 2001;108:1533-1540.

$\checkmark 8$ Bodary PF, Shen Y, Ohman M, Bahrou KL, Vargas FB, Cudney SS, Wickenheiser KJ, Myers MG Jr, Eitzman DT: Leptin regulates neointima formation after arterial injury through mechanisms independent of blood pressure and the leptin receptor/STAT3 signaling pathways involved in energy balance. Arterioscler Thromb Vasc Biol 2007;27:70-76.
-9 Soderberg S, Ahren B, Jansson JH, Johnson O, Hallmans G, Asplund K, Olsson T: Leptin is associated with increased risk of myocardial infarction. J Intern Med 1999;246:409418.

10 Soderberg S, Ahren B, Stegmayr B, Johnson O, Wiklund PG, Weinehall L, Hallmans G, Olsson T: Leptin is a risk marker for firstever hemorrhagic stroke in a populationbased cohort. Stroke 1999;30:328-337.

-11 Taneli F, Yegane S, Ulman C, Tikiz H, Bilge AR, Ari Z, Uyanik BS: Increased serum leptin concentrations in patients with chronic stable angina pectoris and ST-elevated myocardial infarction. Angiology 2006;57: 267-272.

12 Wallace AM, McMahon AD, Packard CJ, Kelly A, Shepherd J, Gaw A, Sattar N: Plasma leptin and the risk of cardiovascular disease in the West of Scotland Coronary Prevention Study (WOSCOPS). Circulation 2001;104: 3052-3056.

-13 Wolk R, Berger P, Lennon R, Brilakis E, Johnson B, Somers V: Plasma leptin and prognosis in patients with established coronary atherosclerosis. J Am Coll Cardiol 2004;44:1819-1824.

14 Shah PK: Circulating markers of inflamma tion for vascular risk prediction: are they ready for prime time. Circulation 2000;101: $1758-1759$.
15 Libby P, Ridker PM, Maseri A: Inflammation and atherosclerosis. Circulation 2002;105: 1135-1143.

16 Ridker PM, Rifai N, Rose L, Buring JE, Cook NR: Comparison of C-reactive protein and low-density lipoprotein cholesterol levels in the prediction of first cardiovascular events. N Engl J Med 2002;347:1557-1565.

17 Pasceri V, Chang J, Willerson JT, Yeh ETH: Modulation of C-reactive protein-mediated monocyte chemoattractant protein-1 induction in human endothelial cells by anti-atherosclerosis drugs. Circulation 2001;103: 2531-2534.

18 Venugopal SK, Devaraj S, Yuhanna I, Shaul P, Jialal I: Demonstration that C-reactive protein decreases eNOS expression and bioactivity in human aortic endothelial cells. Circulation 2002;106:1439-1441.

19 Cirillo P, Golino P, Calabrò P, Calì G, Ragni M, De Rosa S, Cimmino G, Pacileo M, De Palma R, Forte L, Gargiulo A, Granato Corigliano F, Angri V, Spagnuolo R, Nitsch L, Chiariello M: C-reactive protein induces tissue factor expression and promotes smooth muscle and endothelial cell proliferation. Cardiovasc Res 2005;68:47-55.

20 Moshage HJ, Roelofs HMJ, Van Pelt JF, Hazenberg BPC, Van Leeuwen MA, Limburg PC, Aarden LA, Yap SH: The effect of interleukin-1, interleukin-6 and its interrelationship on the synthesis of serum amyloid A and C-reactive protein in primary cultures of adult human hepatocytes. Biochem Biophys Res Commun 1988;155:112-117. 
21 Calabro P, Willerson JT, Yeh ETH: Inflammatory cytokines stimulated C-reactive protein production by human coronary artery smooth muscle cells. Circulation 2003;108: 1930-1932.

22 Calabro P, Chang D, Willerson J, Et Y: Release of C-reactive protein in response to inflammatory cytokines by human adipocytes: linking obesity to vascular inflammation. J Am Coll Cardiol 2005;46:1112-1113.

-23 Yasojima K, Schwab C, McGeer EG, McGeer PL: Generation of C-reactive protein and complement components in atherosclerotic plaques. Am J Pathol 2001;158:1039-1051.

24 Jabs WJ, Theissing E, Nitschke M, Bechtel JFM, Duchrow M, Mohamed S, Jahrbeck B, Sievers HH, Steinhoff J, Bartels C: Local generation of C-reactive protein in diseased coronary artery venous bypass grafts and normal vascular tissue. Circulation 2003;108: 1428-1431.

-25 Visser M, Bouter LM, McQuillan GM, Wener $\mathrm{MH}$, Harris TB: Elevated C-reactive protein levels in overweight and obese adults. JAMA 1999;282:2131-2135.

-26 Fruhbeck G: Intracellular signalling pathways activated by leptin. Biochem J 2006; 393:7-20.
27 Singh P, Hoffmann M, Wolk R, Shamsuzzaman ASM, Somers VK: Leptin induces C-reactive protein expression in vascular endothelial cells. Arterioscler Thromb Vasc Biol 2007;27:e302-e307.

28 Chen K, Li F, Li J, Cai H, Strom S, Bisello A Kelley DE, Friedman-Einat $M$, Skibinski GA, McCrory MA, Szalai AJ, Zhao AZ: Induction of leptin resistance through direct interaction of C-reactive protein with leptin. Nat Med 2006;12:425-432.

29 Bouloumie A, Drexler HCA, Lafontan M, Busse R: Leptin, the product of Ob gene, promotes angiogenesis. Circ Res 1998;83:1059_ 1066.

30 Laufs U, Liao JK: Targeting Rho in cardiovascular disease. Circ Res 2000;87:526-528.

31 Laufs U, La Fata V, Plutzky J, Liao JK: Upregulation of endothelial nitric oxide synthase by HMG CoA reductase inhibitors. Circulation 1998;97:1129-1135.

32 Dreyer MG, Juge-Aubry CE, Gabay C, Lang U, Rohner-Jeanrenaud F, Dayer JM, Meier CA: Leptin activates the promoter of the interleukin-1 receptor antagonist through p42/44 mitogen-activated protein kinase and a composite nuclear factor kappa B/PU.1 binding site. Biochem J 2003;370:591-599.

-33 Takekoshi K, Ishii K, Nanmoku T, Shibuya S, Kawakami Y, Isobe K, Nakai T: Leptin stimulates catecholamine synthesis in a PKC-dependent manner in cultured porcine adrenal medullary chromaffin cells. Endocrinology 2001;142:4861-4871.
34 Blanquicett C, Graves A, Kleinhenz DJ, Hart CM: Attenuation of signaling and nitric oxide production following prolonged leptin exposure in human aortic endothelial cells. J Investig Med 2007;55:368-377.

35 Yasunari K, Maeda K, Minami M, Yoshikawa J: HMG-CoA reductase inhibitors prevent migration of human coronary smooth muscle cells through suppression of increase in oxidative stress. Arterioscler Thromb Vasc Biol 2001;21:937-942.

-36 Kamada Y, Qadota H, Python CP, Anraku Y, Ohya Y, Levin DE: Activation of yeast protein kinase C by Rhol GTPase. J Biol Chem 1996;271:9193-9196.

37 Wickman G, Lan C, Vollrath B: Functional roles of the Rho/Rho kinase pathway and protein kinase $\mathrm{C}$ in the regulation of cerebrovascular constriction mediated by hemoglobin: relevance to subarachnoid hemorrhage and vasospasm. Circ Res 2003;92:809-816.

38 Hippenstiel S, Kratz T, Krüll M, Seybold J, Eichel-Streiber C, Suttorp N: Rho protein inhibition blocks protein kinase $\mathrm{C}$ translocation and activation. Biochem Biophys Res Commun 1998;245:830-834. 